\title{
Determinants of capital structure: An empirical study of companies from selected post-transition economies*
}

\author{
Sasho Arsov ${ }^{1}$, Aleksandar Naumoski ${ }^{2}$
}

\begin{abstract}
The goal of this paper is to examine if there are any determinants that systematically influence the capital structure of the companies in the Balkan countries and to determine if any of the existing capital structure theories are relevant in their case. We apply a panel regression on a sample consisting of the largest and most frequently traded joint-stock companies from four countries. The results show that the larger companies and those with higher fixed asset investments exhibit higher leverage, while the more profitable companies and those with more tangible assets use less debt financing. Other variables, such as the concentration of company ownership, the riskiness of its operating profits and the effective tax rates have not been found statistically significant. These results, supported by the robustness tests, have confirmed our expectation that the managers in these countries do not set specific target leverage ratios, but instead follow a particular order in the selection of the sources of financing. In other words, the companies behave in accordance with the pecking order theory, which is a confirmation of our initial hypothesis. The governments of these countries should put more effort on stimulating the use of other sources of financing to relieve the possible excessive company dependence on the banking sector.
\end{abstract}

Key words: capital structure, transition, leverage, corporate finance, banking

JEL classification: G10, G32, O52

\footnotetext{
* Received: 31-12-2015; accepted: 17-06-2016

1 Full Professor, Faculty of Economics, Ss.Cyril and Methodius University, Bul. Goce Delchev 9V, Skopje, Macedonia. Scientific affiliation: financial management. Phone: +389 23286809. E-mail:sarsov@eccf.ukim.edu.mk.Personalwebsite:http://www.eccf.ukim.edu.mk/Teacher/52/44 (corresponding author).

2 Associate Professor, Faculty of Economics, Ss.Cyril and Methodius University, Bul. Goce Delchev 9V, Skopje, Macedonia. Scientific affiliation: financial and risk management. Phone: +38923286 856. E-mail: aleksandar@eccf.ukim.edu.mk. Personal website: http://www.eccf. ukim.edu.mk/Teacher/52/68.
} 


\section{Introduction}

After Modigliani and Miller had set the basis of the capital structure theory in their seminal paper from 1958, extensive research in this field emerged, aimed at supplementing their findings. In the beginning, this research was mostly focused on recommending a so-called optimal capital structure as a targeted debt-to-equity ratio that would minimize the overall costs of financing. After the works of Myers (1984) and Myers and Majluf (1984), the emphasis changed toward exploring the factors that influence the capital structure under different settings and the objective of the research has shifted towards explaining the reasons companies behave in a particular fashion with respect to their financing, instead of trying to determine a one-size-fits-all solution.

In the last two decades, after the collapse of the socialist system and the emergence of a new economic reality in Eastern Europe, considerably different from the existing economic paradigms, a new field for exploration emerged in the economic science. Namely, contemporary corporate finance is mostly built upon the findings of studies implemented in the mature market economies, most notably the USA. However, it becomes obvious that this wisdom does not exactly match the reality even in the developed countries of continental Europe, not to mention the posttransition economies of Central and Eastern Europe, (Mramor and Valentinčič, 2001; Peev, 2001; Filatotchev et al., 2003; Yeoh, 2007; Bena and Hanousek, 2008; Cvijanovic and Redžepagić, 2011).

The analysis of the capital structure in the post-transition economies of the Balkan countries (with the exception of Slovenia), has been overlooked by the extant literature and to the best of our knowledge, this study is the first to examine this issue. Our research is centred on four countries: Croatia, Macedonia, Serbia and Slovenia. Each of these economies individually seems to be unattractive from academic point of view, most likely because of their size, small available samples, short time series, etc. This paper tries to make a modest contribution towards filling this gap. By extending our field of research to several countries, we expect to obtain a sufficiently large basis for drawing relevant conclusions. We follow the methodology applied in previous studies of this kind. Working with a set of sixyear financial data for the sample of 172 companies, we apply a panel regression analysis using fixed and random effects models.

The primary goal of the paper is to determine if there are any firm-specific factors that systematically influence the capital structure of the companies in the posttransition economies in the Balkans. We find it important to explore how these factors compare to the findings of similar studies for other countries (Gonenc, 2003; Bauer, 2004; Berk, 2007; Črnigoj and Mramor, 2009; Teker et al., 2009, etc.). Our intention is to try to model the behaviour of financial managers if certain common patterns are discovered. Knowledge of this kind could help us develop 
general conclusions about larger groups of countries, in this case the post-transition economies. The detection of the capital structure determinants would also enable us to identify the theory that best describes the capital structure decision-making practices in these countries. On the basis of these findings, we intend to derive conclusions regarding the probable causes and implications of these practices.

Having in mind the characteristics of the analyzed economies, i.e. the shallow capital markets, low corporate tax rates, the importance of banks and the informal company-bank relationships, as well as taking into account the findings from previous studies on the post-transition economies, our basic hypothesis is that it is the pecking order theory that could find support in the empirical data. In other words, our initial assumption is that the companies in the region do not set target debt-equity ratios, but rather utilize their own funds and once they are exhausted, they resort to borrowing. Issuing equity is the last choice.

The second part of the paper presents a review of the most relevant literature in the field. It provides a brief insight into the most representative contributions that laid down the fundaments of the capital structure theory. The third section contains an elaboration of the research methodology. First, we make an overview of the existing studies on determinants of capital structure and then on the basis of these experiences, we develop our hypotheses and the regression model. The fourth section contains information on the sample used and the features of the financial sectors of the analyzed countries. The results of the regression analysis and the discussion on the identified impact of the variables are given in the fifth section. The last section summarizes the conclusions of the study and identifies areas for further research.

\section{Literature review}

As mentioned above, the foundations of the theory were set by Modigliani and Miller (MM) in 1958, when they conclude that under certain assumptions, the value of the firm is not dependent on the financing mix, i.e. the capital structure is irrelevant. In 1963, they relaxed the assumption on non-existence of corporate taxes, which resulted in the hardly sustainable conclusion that $100 \%$ debt is the optimal level. Miller's revision from 1977 in which he takes into account the personal income taxes ends with the finding that the differential tax impact on debt and equity holders shrinks the previously glorified interest tax shield. The taxshield stance has been further supported by DeAngelo and Masulis (1980) through the inclusion of non-debt tax shields. Therefore, in the course of two decades, the theory on capital structure has been enriched with a number of helpful insights, but it has hardly made any advance from the beginning positions regarding the solution of the optimal capital structure puzzle (Myers, 1984). The future contributions to 
the static trade-off theory attempt to overcome one of the biggest weaknesses of the MM propositions - the ignoring of the inevitable consequences of overleveraging. Jensen and Meckling (1976), claim that the benefits of the debt tax shield at some point become offset by the direct and indirect costs of borrowing.

Apart from the purely theoretical reasoning, a more practical line of research emerged which deviates from the static view of existence of a target capital structure as a predetermined ratio. The so-called pecking order theory announced by Myers (1984) and elaborated in more detail in Myers and Majluf (1984) claims that instead of targeting a specific debt-equity ratio, the managers follow a sequence of steps trying to minimize the negative consequences of information asymmetries. Higher leverage could also serve as a preventive device to limit managerial discretion over free cash flows (Grossman and Hart, 1982, Jensen, 1986). Baker and Wurgler (2002) link the capital structure puzzle to the market timing theory and assert that the capital structure is a result of the past decisions of the companies to issue equity in periods with the highest market valuations of their shares.

Harris and Raviv (1991) contend that the empirical research has in most cases confirmed the existing theories. However, as a number of determinants of capital structure have been identified, "the empirical work has not sorted out which of these are important in particular contexts" (Harris and Raviv, 1991, p. 299). Their findings have probably initiated the latest wave of research in this field. In the last two decades, most of the studies have focused on exploring the significance of particular determinants of the capital structure.

As of the end of the 1990s, most of the studies on the topic have been based on data from the mature market economies. However, different institutional settings make it impossible to simply transfer the capital structure theory across countries (Booth et al., 2001). Only in the recent two decades we have come to see increased academic interest to extend the relevance of the capital structure theory to the developing countries and the emerging economies. Examples of this trend include DemirgüçKunt and Maksimovic (1999), Booth et al. (2001), Gonenc (2003), Keister (2004), Benkato et al. (2005), Teker et al. (2009), etc.

Nivorozhkin is among the first scholars to delve into the area of capital structure in the economies in transition. His study on Hungary (2002) concludes that during the early stages of capital market development, higher leverage has been characteristic for the companies from the manufacturing sector and those in which the state retained a larger ownership stake. Later (2004), he investigated the financing choices of five EU accession countries.

Wen et al. (2002) examine the impact of corporate governance on leverage in the case of the Chinese listed companies and conclude that the use of debt as a source of financing is affected by the composition of the board of directors. Bauer (2004) uses a sample of 74 companies listed on the Prague Stock Exchange to explore 
the most important determinants of their capital structure. In the Balkans, the first relevant study is the one by Berk (2007) and later by Črnigoj and Mramor (2009), both of them dealing with Slovenian companies. Avarmaa et al. (2011) extend the research on capital structure to the companies in the Baltic states.

The findings on the capital structure in the transitional economies are probably best enveloped by Delcoure (2007). She asserts that none of the known theories provides a satisfactory explanation of the debt-equity choice in these countries. Mostly as a result of corporate governance related factors, the companies from these countries follow some kind of a "modified pecking order" in the selection of financing choices.

\section{Research methodology}

\subsection{Determinants of capital structure in empirical research}

Contemporary research on the capital structure decisions generally focuses on determining the most important factors that influence the actual capital structure of the companies under different settings. Here we provide a brief review of the determinants most frequently used in these studies along with the reasons for their use.

Size. The size of the company is expected to be positively related to its level of debt because larger companies are perceived as more stable and thus more reliable from lenders' point of view. Additional arguments in favour of this proposition are that larger companies usually have more diversified operations, which makes them more resistant to shocks in the long run (Rajan and Zingales, 1995) and they are often listed on stock exchanges and more transparent, which results in lower agency costs (Jensen and Meckling, 1976), etc.

However, this relationship is far from unambiguous. According to the theory on information asymmetries, size may be inversely related to the amount of information available to external investors, who thus might prefer to hold equity rather than debt (Rajan and Zingales, 1995).

The size of the company has an additional meaning in our case. Namely, most (though not all) of the large companies in this region belong to the group of former socialist state-owned enterprises, that managed to survive (and expand) after the privatization. These companies still maintain a reputation of longevity and sustainability which is helpful with regards to borrowing from banks.

Tangibility of assets. It is expected that asset tangibility should have a positive impact on the ability of the company to repay its debt and consequently on the willingness of the banks to extend loans to their clients. According to Myers and 
Majluf (1984), by issuing collateralized debt the companies reduce information asymmetries and obtain capital at more favorable terms. This argument is based on the accounting treatment of the assets, but their real value as a collateral is ambiguous depending on the economic conditions, the specificity of the assets, the industry in which the company operates, etc. Additionally, the costs of financial distress increase as a result of the uniqueness of the assets when it is linked to the uniqueness of the labor skills needed, which lowers the ability of the company to borrow (Titman and Wessels, 1988).

Profitability. According to the conventional wisdom, the borrowing needs of the profitable companies are lower, which is in line with the pecking order theory (Higgins, 1977). On the other hand, the more profitable companies find it easier to borrow, as a result of the (presumably) less uncertain cash flows. Also, the static trade-off theory implies that the more profitable companies are induced to borrow more, because the debt and non-debt tax shields are functional only when the company makes profits. These arguments, however, fail to differentiate between accounting profits and cash-flows which are far more useful when borrowing needs are estimated. The free cash flow theory also supports the view that the companies with abundant profits should use more debt as a safeguard from managerial selfdealing (Jensen, 1986).

Growth and growth opportunities. These variables are used interchangeably in many articles although they are not equivalent. According to the pecking order theory, the desire for faster growth at a constant level of profitability necessitates the use of more debt. The theory on information asymmetries implies that the companies with strong growth potential should avoid issuing new equity because the market undervalues their shares. On the other hand, the market timing theory asserts that when price-to-book $(\mathrm{P} / \mathrm{B})$ ratios are high, which is an indicator of the growth potential of a company, issuing equity is advisable (Baker and Wurgler, 2002). Finally, the trade-off theory links growth to the rising risk of financial distress and the accompanying debt-related agency problems, so it predicts a negative relationship between growth and leverage (Myers, 1977; Rajan and Zingales, 1995).

Tax shields. The earliest recommendations regarding the choice of the optimal leverage ratio were related to the debt tax shield (Modigliani and Miller, 1963). The tax shield resulting from interest payments should induce increased use of debt. Later, the importance of this proposition has been reduced by the trade-off theory. Although numerous studies have failed to confirm this relationship, MacKie-Mason (1990) provides significant support to this hypothesis using the impact of taxes on incremental financing choices.

The importance of tax shields critically depends on the level of tax rates. One should bear in mind that the relative tax burden in many countries today is 
significantly lower than the one that prevailed in the times of Modigliani's and Miller's work. Also, the empirical studies in many cases have so far failed to prove the utilization of tax shields by the companies in this respect, mostly because they have been based on debt/equity ratios, rather than on incremental borrowing decisions (MacKie-Mason, 1990, p. 1471).

Risk. The riskiness of the borrower affects the creditors' attitudes, but it also makes prospective investors more cautious. The operational risk of a company is a result of the volatility of its earnings and consequently, its cash-flows. A company with highly volatile earnings would face higher borrowing costs and its optimal level of debt would be lower (Titman and Wessels, 1988). However, from asymmetric information theory perspective, the higher volatility increases the systematic risk of the company, thus reducing the prospects for issuing new equity (Harris and Raviv, 1990). Kim and Sorensen (1986) find a positive relation, but Titman and Wessels (1988) and Bauer (2004) find no significant relationship between risk and leverage.

Ownership structure. The impact of the structure of company shareholders has been explored in a number of studies. In some of them, the division between foreign and domestic owners has been determined to have some influence on the capital structure (Chen et al., 2013), while in others, the percentage of state ownership has been considered as a possible factor (Nivorozhkin, 2002; Al-Najjar and Taylor, 2008; Chen et al., 2013). Friend and Lang (1988) find that the level of debt is higher in the companies with significant managerial ownership. The same finding is confirmed by Gonenc (2003) in the case of Turkey, who also asserts that the participation of financial institutions and the government in the company has an opposite impact.

Other determinants. The list of potential factors is far from exhaustive and numerous authors have investigated the possibility that other variables could have a significant influence on the capital structure.

Frank and Goyal (2004) using a sample of American firms throughout a period longer than five decades, investigate the impact of stock and debt market conditions, as well as macroeconomic settings on leverage. Titman and Wessels (1988) and Bauer (2004) analyze the impact of the industry to which the company belongs, using a dummy variable.

Using a large sample of firms, Jiraporn and Gleason (2007) analyze the impact of shareholder rights on leverage and conclude that there is an inverse relationship between the degree of protection of shareholder rights and the level of debt used. Berger et al. (1997, p.1436) claim that "leverage is lower when CEOs have long tenure in office, have weak compensation incentives and do not face strong monitoring from the board or the major shareholders". The researchers recognize that the importance of particular determinants of capital structure varies in different 
situations or among the companies working in different conditions. Booth et al. (2001) conclude that the differences among the countries are persistent, so that general knowledge is not applicable in each and every particular country.

Apparently, the findings on the capital structure determinants and the sign of their impact are ambiguous. For this reason, we provide a review of a number of selected studies on this issue, listed by the names of their authors, along with the statistically significant regression coefficients. Because of the size of the table, this review is placed in Appendix 1.

\subsection{Regression model}

For the purposes of developing our working hypothesis and an appropriate regression model, we have selected the firm-specific variables which have most often been analyzed in similar studies. For the selected variables, we apply the commonly used proxies.

Leverage. This is a dependent variable with a key role in the model. The most commonly used alternative is the total leverage as a ratio of total liabilities to total assets. It is based on the broadest definition of debt and reflects the general division of the sources of financing between equity and borrowed funds. Another option is the total debt to total assets ratio. Total debt includes only interest-bearing liabilities such as long-term and short-term bank debt. In addition to these, we will also use another measure of leverage - the long-term debt ratio. Its usage can be justified on the ground that short-term borrowing is usually used to cover temporary shortages of cash and it has little to do with the long-term capital structure policy of the company.

Size. The proxies most often suggested for company size are the natural log of the total assets or the log of sales revenues. As theory suggests, larger companies are more reliable as borrowers.

Tangibility of assets. The importance of this variable for our model is augmented by the fact that the banks' lending decisions in these countries extensively rely on the available collateral which is mostly found in the companies' tangible fixed assets. The most usual proxy for asset tangibility is the ratio of tangible fixed assets to total assets (our choice, too), while an option with the opposite meaning is the amount of R\&D expenditures, implying higher degree of asset specificity and thus, their lower applicability as a collateral (Durnev and Kim, 2005).

Profitability. One of the most logical determinants of the borrowing capacity is the profitability of the company. Since most of the studies have shown that the more profitable companies need less additional funding (pecking order theory) (Bauer, 2004; Avarmaa et al., 2011; Kędzior, 2012), we expect a negative sign. We use the ratio of operating profit to total assets (ROA) to proxy this variable. 
Growth or growth opportunities. Growth opportunities are usually proxied by the price-to-book ratios $(\mathrm{P} / \mathrm{B})$, on the basis of the widely accepted interpretation of a higher $\mathrm{P} / \mathrm{B}$ ratio as an indicator that the company with a growth potential is worth more than the book value of its assets.

However, in less liquid capital markets, where share valuations are doubtful and the companies' R\&D investments are negligible, a more appropriate proxy could be the capital expenditures to total assets ratio or the change in the log of assets (Titman and Wessels, 1988). In some cases, the Tobin's Q is used as a proxy for the growth opportunities (Okuda and Nhung, 2012) or the growth rate of the sales in the last few years (Črnigoj and Mramor, 2009; Kędzior, 2012).

Having in mind the features of the stock markets in the analyzed countries, the amount of fixed capital investments is our first choice. In order to reflect the longrun effects of investments, we use the ratio between the cumulative three-year amount of fixed capital investments from the cash-flow statements and the total assets in the last year of the respective three-year period. We expect that companies with higher cumulative amounts of fixed asset investments should be more leveraged.

Despite the limitations of the $\mathrm{P} / \mathrm{B}$ ratio elaborated above, we use it in at least one of the model specifications. The trade-off theory and the market timing theory predict a negative sign, while the pecking order theory predicts a positive value for this variable. Our general expectation is that the regional capital markets are not very efficient and the benefits of higher market valuations are unlikely to be seized, so we predict a positive sign.

Risk. The riskiness of the borrower is usually measured by the variance of the operating profits. We use the standard deviations of company ROAs based on the operating income for the last 3 years as a measure of riskiness. The expected sign is negative.

Tax shields. The most obvious candidate to proxy the importance of tax shields is the effective tax rate, since it incorporates the impact of various tax deductions. It is the ratio of the difference between the pre-tax and after-tax earnings and the pre-tax earnings. In our study, we have used two-year averages of the effective tax rates in order to neutralize the possible impact of tax credits, tax-loss carry-forwards, etc. A positive sign for this variable indicates behavior in line with the trade-off theory.

Ownership. The support for the use of this variable is found in the research on corporate governance (Berglöf and Pajuste, 2005; Boubaker et al., 2012). Concentrated ownership is usually considered harmful to corporate governance and thus we find a similarity between insider ownership and concentrated ownership. We use the percentage of shares owned by the three largest shareholders as an absolute figure. We expect that companies controlled by smaller numbers of 
dominant shareholders would be prone to borrow more, instead of issuing additional equity to prevent loss of control over the company (Jiraporn and Gleason (2007) find an inverse relationship between the quality of shareholder rights protection and leverage).

We do not consider industry effects because the sample is very diversified and the various industries are not sufficiently represented in the sample. Later, in the robustness check we make a global division to manufacturing and services sectors.

The basic regression model we use in this paper can be specified as:

$$
\begin{aligned}
\text { LEVER }_{i, t}= & \alpha+\alpha_{1} \text { TANG }_{i, t}+\alpha_{2} \text { SIZE }_{i, t}+\alpha_{3} \text { PROF }_{i, t}+\alpha_{4} I N V_{i, t 3 y}+ \\
& +\alpha_{5} \text { GROWTH }_{i, t}+\alpha_{6} \text { RISK }_{i, t 3 y}+\alpha_{7} T A X_{i, t 2 y}+\alpha_{8} \text { OWN }_{i, t}+\varepsilon_{i, t}
\end{aligned}
$$

The meaning of the regressors is as follows:

- LEVER $_{\mathrm{i}, \mathrm{t}}$ - leverage of the $i_{t h}$ company in period $t$

- TANG $_{\mathrm{i}, \mathrm{t}}-$ tangibility of assets of the $i_{t h}$ company in period $t$

- SIZE $_{\mathrm{i}, \mathrm{t}}-$ size of the $i_{t h}$ company in period $t$

- $\mathrm{PROF}_{\mathrm{i}, \mathrm{t}}-$ profitability of the $i_{t h}$ company in period $t$

- $\mathrm{INV}_{\mathrm{i}, 3}$ - fixed assets investments of the $i_{t h}$ company in the last three years

- GROWTH Git, $_{-}$market-to-book ratio of the $i_{t h}$ company in period $t$

- RISK $_{\mathrm{i}, 3 \mathrm{y}}$ - standard deviation of ROA of company $i$ for the past three-year period

- $\mathrm{TAX}_{\mathrm{i}, \mathrm{t2}}-$ effective tax rate of company $i$ for the past two years (average)

- $\mathrm{OWN}_{\mathrm{i}, \mathrm{t}}-$ percentage of equity held by the top three shareholders of the $i_{t h}$ company in period $t$

$-\varepsilon_{i, t}$ - error term for firm $i$ in period $t$

\section{Empirical data and analysis}

For the purposes of our research, we have created a sample consisting of companies from these four countries consistent enough to derive conclusions that would be helpful in explaining the leverage-related behavior of the corporate executives in the region. We have assembled data from the publicly available financial statements of the joint-stock companies in the four countries. As a result, the sample is biased toward including only joint-stock companies, which, in most cases represent privatized former socialist enterprises. Here we must make an important note regarding the representativeness of the sample. First, it is only the joint-stock companies that are eligible to obtain additional financing by issuing securities, and second, all the analyzed economies are rather small, covering a total population of about 15 million people, so that the companies in the sample are among the largest in the respective countries and account for a major part of their national GDPs. 
Our database covers the period 2008-2013. The initial sample contained 207 nonfinancial companies, but for the purposes of better consistency we have eliminated a number of them, such as companies undergoing bankruptcy during a part of the analyzed period, companies with insufficient data available or companies with negative equity capital. Therefore, the final sample consists of a total of 172 publicly traded companies (50 companies from Croatia, 53 from Macedonia, 32 from Slovenia and 37 from Serbia). For some of the included companies, the data were not available for the entire analyzed period. The financial sector is excluded from this type of analysis, due to the specificity of its capital structure.

The representativeness of the sample is supported by the fact that the analyzed companies represent a significant share in the total market capitalization of the publicly traded companies in these countries and the trading with their shares accounts for a major part of the total market turnover. All the analyzed countries have adopted the use of IFRS and IAS for publicly traded companies. Therefore, the financial statements used in this sample can be considered consistent and mutually comparable.

In order to set the basis for the analysis, it would be useful to get some idea on the basic features of the financial systems of these countries. A summary of financial data is presented in table 1 .

Table 1: Basic features of the financial sectors in the analyzed countries

- values in millions of Euro unless otherwise stated

\begin{tabular}{|l|r|r|r|r|}
\hline \multicolumn{1}{|c|}{ Data for 2013 } & Croatia & Macedonia & \multicolumn{1}{c|}{ Serbia } & Slovenia \\
\hline GDP (nominal in billion US dollars) & 57.9 & 10.2 & 45.5 & 48.0 \\
\hline GDP per head (PPP, in current dollars) & 21,351 & 11,612 & 13,020 & 28,859 \\
\hline Banking sector & & & & \\
\hline Number of banks & 30 & 16 & 30 & 17 \\
\hline Total assets & 52,356 & 6,008 & 25,157 & 39,700 \\
\hline Total loans to non-financial sectors & 34,535 & 3,282 & 14,661 & 32,470 \\
\hline Loan/deposit ratio & $93.3 \%$ & $88.8 \%$ & $127 \%$ & $103.2 \%$ \\
\hline Percentage of foreign ownership & 89.7 & 75.20 & $68.7^{*}$ & 31 \\
\hline Total assets of open-end investment funds & 1,706 & 12.2 & 46.0 & 1,860 \\
\hline Total assets of mandatory pension finds & 7,623 & 441 & 177 & 1,475 \\
\hline Capital market & \multicolumn{5}{|c|}{} \\
\hline Stock market capitalization - all shares & 15,573 & 1,670 & 5,989 & 5,200 \\
\hline Capitalization as a \% of GDP (all shares) & 26.5 & 20.6 & 18.7 & $14.7 \%$ \\
\hline Total market turnover & 498.3 & 52.6 & 252.0 & 299.4 \\
\hline Turnover of shares in classical trading ${ }^{* *}$ & 355.6 & 22.7 & 237.1 & 288.1 \\
\hline
\end{tabular}


Sasho Arsov, Aleksandar Naumoski • Determinants of capital structure: An empirical study...

Table 1 (continuation)

\begin{tabular}{|l|r|r|r|r|}
\hline Number of listed companies & 23 & 115 & 8 & 10 \\
\hline Share of financial sector assets in GDP & $113,3 \%$ & $89 \%$ & $80 \%$ & $162 \%$ \\
\hline $\begin{array}{l}\text { Share of banking sector assets in the financial } \\
\text { sector assets }\end{array}$ & $83 \%$ & $87,6 \%$ & $92,4 \%$ & $75 \%$ \\
\hline
\end{tabular}

Notes: The data shown are end of year figures, except for turnover which is the annual amount.

* For Serbia, this is the percentage of foreign-owned banks in the number of total banks. For the other countries, it is the percentage of equity owned by foreign owners.

** Classical trading excludes block trades.

Sources: Croatian National Bank, HANFA (Croatian Agency for Supervision of Financial Services, National Bank of the Republic of Macedonia; Macedonian Stock Exchange); Serbian National Bank; Belgrade Stock Exchange, Securities and Exchange Commission of Serbia; Slovenian National Bank, Ljubljana Stock Exchange. For GDP: World Bank Data. The table includes authors' own calculations

Obviously, all the analyzed economies are clearly bank-centered. The share of the banking sector assets in the total assets of the financial sector ranges between $75 \%$ and $92.4 \%$. In all these countries with the exception of Slovenia, most of the banks are owned by foreign investors, but it seems that the foreign ownership has not resulted in a meaningful improvement of their efficiency (Košak and Čok, 2008). After the establishment of the national stock exchanges, the capital markets have been developing slowly with a short booming episode around 2007. The IPOs are rare, as well as the use of corporate bonds for financing. The number of voluntarily listed companies is rather low.

The banks are mostly financed from deposits and the loan-to-deposit ratios rarely exceed $100 \%$. In the four countries, the aggregate bank deposits amount to about 80 billion euros which by far exceeds the total stock market turnover or the total market capitalization. It also illustrates the preference of the domestic investors towards the various investing opportunities (Ribnikar and Košak, 2011). The ratios of stock market capitalization to GDP range between $15 \%$ and $40 \%$, but these numbers should be taken with caution, because of the very low level of liquidity for most of the shares. The stock turnover ratio is around the 5\% of the GDP figure, while in most of the developed economies it is higher than $20 \%{ }^{3}$

The descriptive statistics of the sample is included in table 2 .

$\overline{3}$ Source: World Bank Database. 
Table 2: Descriptive statistics

\begin{tabular}{|l|c|c|r|r|r|r|r|r|r|}
\hline Variable & $\begin{array}{c}\text { Total } \\
\text { Liabilities }\end{array}$ & $\begin{array}{c}\text { LT } \\
\text { Debt }\end{array}$ & $\begin{array}{c}\text { Total } \\
\text { Debt }\end{array}$ & Size & Tang & ROA & Invest. & $\begin{array}{c}\text { Tax } \\
\text { Rate }\end{array}$ & $\begin{array}{c}\text { Top 3 } \\
\text { owners }\end{array}$ \\
\hline Mean & 0.45 & 0.10 & 0.23 & 10.816 & 0.554 & 0.032 & 0.117 & 0.216 & 62.89 \\
\hline Median & 0.44 & 0.07 & 0.20 & 10.762 & 0.544 & 0.029 & 0.095 & 0.09 & 66.10 \\
\hline Max & 0.97 & 0.60 & 0.86 & 15.258 & 0.991 & 0.470 & 2.209 & 18.63 & 100 \\
\hline Min & 0.003 & 0.00 & 0.08 & 6.769 & 0.155 & -0.128 & -3.028 & -0.093 & 8.52 \\
\hline StDev & 0.223 & 0.109 & 0.178 & 1.642 & 0.217 & 0.085 & 0.223 & 0.756 & 23.346 \\
\hline Skew & 0.103 & 0.880 & 0.544 & 0.080 & 0.025 & -1.219 & -1.35 & 2.742 & -0.337 \\
\hline Kurtos & 2.223 & 2.920 & 2.567 & 2.702 & 2.403 & 14.105 & 7.38 & 11.8 & 2.099 \\
\hline
\end{tabular}

Source: Authors' calculations

One would logically expect that the companies in the bank-centered economies prefer to use bank loans instead of issuing equity or bonds. However, it tells us little about the levels of leverage and its determinants, and it is the purpose of this research to determine them.

\section{Results and discussion}

Working with panels of data, we are facing the choice between applying fixed or random effects models. These techniques enable time-invariant inter-firm heterogeneity to be controlled. The use of fixed vs. random effects was based on the Hausman test and in the cases where the level of significance of the ChiSquared test was lower than $5 \%$, we have applied a fixed effects model and the random effects model otherwise. We begin with the assumption that the companies in the sample are heterogeneous, so that the fixed effects model would be more appropriate, but we use additional tests to prove that proposition. We apply OLS regression using several variations of the basic model. The regression results are given in table 3 .

The first four specifications use the fixed effects model, while in the fifth case, the random effects model has proven more appropriate on the basis of the Hausman test. The adjusted $\mathrm{R}^{2}$ results indicate that the validity of the last model is questionable. 
Sasho Arsov, Aleksandar Naumoski • Determinants of capital structure: An empirical study...

Table 3: Regression results

\begin{tabular}{|c|c|c|c|c|c|}
\hline \multirow{2}{*}{$\begin{array}{l}\text { Dependent } \\
\text { variable }\end{array}$} & Model 1 & Model 2 & Model 3 & Model 4 & Model 5 \\
\hline & $\begin{array}{c}\text { (Total } \\
\text { Liabilities) }\end{array}$ & $\begin{array}{c}\text { (Total } \\
\text { Liabilities) }\end{array}$ & $\begin{array}{c}\text { (Total } \\
\text { Liabilities) }\end{array}$ & $\begin{array}{l}\text { (Long-Term } \\
\text { Debt) }\end{array}$ & $\begin{array}{l}\text { (Total } \\
\text { Debt) }\end{array}$ \\
\hline \multirow{2}{*}{ Constant } & -0.0058 & 2.7849 & 2.5878 & $3.4378^{* * *}$ & -0.0830 \\
\hline & $(0.1988)$ & $(1.9548)$ & $(1.8829)$ & $(1.2652)$ & $(0.0746)$ \\
\hline \multirow{2}{*}{ Tangibility } & $-0.1624^{* * *}$ & $-0.1630^{* * *}$ & $-0.1352^{* * *}$ & $-0.5728^{* *}$ & $0.0738^{* *}$ \\
\hline & $(0.0450)$ & $(0.0450)$ & $(0.0432)$ & $(0.2866)$ & $(0.0301)$ \\
\hline \multirow{2}{*}{ Size } & $0.0508^{* * *}$ & $0.0517^{* * *}$ & $0.0885^{* * *}$ & $-0.2659^{* *}$ & $0.0252^{* * *}$ \\
\hline & $(0.0175)$ & $(0.0176)$ & $(0.0172)$ & $(0.1117)$ & $(0.0065)$ \\
\hline \multirow{2}{*}{ Profitability } & $-0.2833^{* * *}$ & $-0.2854^{* * *}$ & $-0.3091^{* * *}$ & 0.1266 & $-0.1373^{* * *}$ \\
\hline & $(0.0492)$ & $(0.0491)$ & $(0.0556)$ & $(0.3129)$ & $(0.0390)$ \\
\hline \multirow{2}{*}{$\begin{array}{l}\text { Growth } \\
\text { (investments) }\end{array}$} & $0.0721^{* * *}$ & $0.0715^{* * *}$ & & 0.1217 & 0.0063 \\
\hline & $(0.0180)$ & $(0.0180)$ & & $(0.1148)$ & $(0.0143)$ \\
\hline \multirow{2}{*}{$\begin{array}{l}\text { Growth } \\
\text { opportunities } \\
(\mathrm{P} / \mathrm{B})\end{array}$} & & & $0.0146^{* * *}$ & & \\
\hline & & & $(0.0026)$ & & \\
\hline \multirow{2}{*}{ Risk } & -0.0714 & -0.0712 & $-0.2787^{* * *}$ & $1.5712^{* * *}$ & 0.0139 \\
\hline & $(0.0712)$ & $(0.0711)$ & $(0.0820)$ & $(0.4529)$ & $(0.0563)$ \\
\hline \multirow{2}{*}{$\begin{array}{l}\text { Tax shield (tax } \\
\text { rate) }\end{array}$} & -0.0025 & -0.0025 & $-0.0076^{*}$ & -0.0126 & -0.0009 \\
\hline & $(0.0022)$ & $(0.0022)$ & $(0.0041)$ & $(0.0139)$ & $(0.0018)$ \\
\hline \multirow{2}{*}{$\begin{array}{l}\text { Ownership } \\
\text { concentration }\end{array}$} & & -0.0445 & -0.0482 & & \\
\hline & & $(0.0310)$ & $(0.0300)$ & & \\
\hline $\begin{array}{l}\text { No. of } \\
\text { observations }\end{array}$ & 972 & 972 & 972 & 972 & 972 \\
\hline Adjusted $\mathrm{R}^{2}$ & 0.8457 & 0.8459 & 0.8553 & 0.32257 & 0.02945 \\
\hline AIC & -1.8658 & -1.8664 & -1.9347 & 1.8353 & n.a. \\
\hline Prob (F-Statistics) & 0.0000 & 0.0000 & 0.0000 & 0.0000 & 0.0000 \\
\hline Model used & Fixed effects & Fixed effects & Fixed effects & Fixed effects & $\begin{array}{c}\text { Random } \\
\text { effects }\end{array}$ \\
\hline $\begin{array}{l}\text { Hausman test for } \\
\text { random effects } \\
\text { (prob. Chi-Sq.) }\end{array}$ & 0.0447 & 0.0479 & 0.0011 & 0.0032 & 0.2194 \\
\hline
\end{tabular}

Note: Standard errors in parenthesis; ${ }^{*}$ significant at $10 \%,{ }^{* *}$ significant at $5 \%,{ }^{* * *}$ significant at $1 \%$.

Source: Authors' calculations

As table 3 shows, the variations of the model using the total liabilities as a dependent variable seem to have the highest explanatory power, according to the adjusted $\mathrm{R}^{2}$ and AIC criteria. Almost all the variables exhibit statistical significance in some of the variants of the model, but those that show the highest consistency are tangibility, size and profitability.

It appears that leverage is positively related to the size of the company and negatively to the tangibility of the company assets. The size of the company has the expected sign in all the model specifications using total leverage and total debt. We 
interpret the impact of size as an illustration of the better availability of bank credit to larger companies in general and the importance of informal relations between the lenders and the borrowers, which are quite common in the small countries. This result is in line with our first hypothesis and it also corresponds to the results of most of the other similar studies, as shown in table A1 in Appendix 1.

The sign of the asset tangibility regressor is to some extent surprising having in mind that the available collateral plays an important role in the banks' lending decisions. It can be explained on the ground that the companies which are already better equipped with fixed assets need to invest less and therefore, have lower borrowing needs. Other papers exploring the capital structure in the developing countries have also found a negative relationship (Booth et al., 2001; Bauer, 2004; Črnigoj and Mramor, 2009; Jõeveer, 2013) and these results, especially those by Črnigoj and Mramor, based on a sample that overlaps with ours, strengthens our confidence in the results obtained, although they contradict some of our assumptions.

More profitable companies tend to borrow less, which is expected and corresponds to the pecking order theory. This is a variable with the highest degree of consistency in our model. It is also compatible with the findings of most of the other studies. Bauer (2004), Nivorozhkin (2004), Berk (2007), Črnigoj and Mramor (2009), Avarmaa et al. (2011), Kędzior (2012) are representative for the research stream covering the post-transition economies, but the results of Hernádi and Ormos (2012) and Jõeveer (2013) in the case of listed firms fail to support this.

The positive sign of the variable representing the investment activity confirms our expectation. The companies' investments in fixed assets in the previous years have obviously been backed by increased reliance on external funds. However, models 4 and 5 do not provide sufficient proof that only bank loans are used for this purpose, so we can conclude that not only loans, but also other liabilities increase as a result of the investing activity, partially transferring the burden on the company suppliers and other stakeholders. Titman and Wessels (1988) obtained an insignificant result on this variable, so we lack the basis to make comparisons.

The price-to-book ratios seem to be positively related to leverage. Booth et al. (2001), Gonenc (2003) and Črnigoj and Mramor (2009) have found a negative relationship, but Titman and Wessels (1988) obtained a positive impact. Our positive sign is in accordance with the theory on information asymmetry and the pecking order theory, which assert that managers not being able to transfer the positive expectations to the investors refrain from issuing shares. Also, in illiquid markets the companies are less able to take advantage of the higher valuations and "time the market". The insufficient liquidity and depth of the market are also pointed out by Berk (2007) who finds this variable insignificant in the case of the Slovenian companies. 
We do not find a reliable relationship between leverage and the volatility of past profits, which is not surprising. Being familiar with the practices of the local banks, we know that most of the banks' lending decisions are based on the viability of the proposed projects and the collateral provided, while the past volatility plays a minor role, if at all. This is compatible with the general stream of research, where only one of the studies covering the post-transition economies found a negative relationship (Črnigoj and Mramor, 2009), while in all other cases this variable failed to give a statistically significant result.

The impact of corporate taxes is also found to be inconclusive, which was expected because the corporate income tax rates in the analyzed countries are considerably lower than those in Western Europe and the USA, so that the tax shield loses its appeal. In the comparable studies, we only find a positive relationship between tax rates and leverage in Bauer (2009) and Kędzior (2012), negative in Kim and Sorensen (1986) and Booth et al. (2001), while Avarmaa et al. (2011) find no significant relationship.

The ownership concentration variable failed to provide significant coefficients. The closest comparisons are the papers operating with managerial ownership (Gonenc, 2003, positive relationship) and insider ownership (Kim and Sorensen, 1986, positive). We leave open the possibility that a different proxy could have provided better conclusions, so we suggest future studies to pay more attention to the impact of company ownership on leverage, especially if more detailed data is available.

To test the robustness of the results, we have run several additional regressions. In the first test, we have included only the companies for which complete six-year data are available. This accounts for a total of 140 companies. The second check is based on the division of companies by sector and for this purpose we divide all the companies in two general groups: manufacturing and services (using the criteria applied by Antoniou et al., 2008). The third test involves a division of the companies by size (large and small), using a 50-50 classification of the entire sample by the log of assets criterion. The last test is related to the status of the companies as being listed on a stock exchange or not. However, this is not a permanent situation, since some of the companies have been delisted during the analyzed period and others have applied for listing. The classification criterion we have applied is that a company should be included in this subsample if it has been listed for at least 4 years out of 6 and we have found 56 such companies. In all these variations of the model, the total leverage is used as a dependent variable. The results of these tests are given in table 4 . 
Sasho Arsov, Aleksandar Naumoski • Determinants of capital structure: An empirical study...

Table 4: Robustness check

\begin{tabular}{|c|c|c|c|c|c|c|c|}
\hline \multirow[b]{2}{*}{ Variable } & \multirow{2}{*}{$\begin{array}{l}\text { Companies } \\
\text { with } \\
\text { complete } \\
\text { data set }\end{array}$} & \multicolumn{2}{|c|}{ Industry } & \multicolumn{2}{|c|}{ Size } & \multicolumn{2}{|c|}{$\begin{array}{c}\text { Stock exchange } \\
\text { listing }\end{array}$} \\
\hline & & $\begin{array}{c}\text { Manu- } \\
\text { facturing }\end{array}$ & Services & Large & Small & Listed & Not listed \\
\hline \multirow{2}{*}{ Constant } & 2.601 & 2.777 & $0.423^{* *}$ & 0.074 & $0.370^{* *}$ & -0.533 & 0.189 \\
\hline & $(1.958)$ & $(1.917)$ & $(0.198)$ & $(0.199)$ & $(0.187)$ & $(0.585)$ & $(0.126)$ \\
\hline \multirow{2}{*}{ Tangibility } & $-0.158^{* * *}$ & $-0.173^{* * *}$ & $-0.151^{* *}$ & $-0.163^{* *}$ & $-0.185^{* * *}$ & $-0.219^{* * * *}$ & $-0.162^{* * *}$ \\
\hline & $(0.048)$ & $(0.051)$ & $(0.077)$ & $(0.044)$ & $(0.062)$ & $(0.076)$ & $(0.046)$ \\
\hline \multirow{2}{*}{ Size } & $0.064^{* * *}$ & $0.067^{\text {*** }}$ & 0.018 & $0.053^{* *}$ & 0.012 & $0.116^{\text {*** }}$ & $0.042^{* * *}$ \\
\hline & $(0.019)$ & $(0.022)$ & $(0.015)$ & $(0.015)$ & $(0.018)$ & $(0.035)$ & $(0.010)$ \\
\hline \multirow{2}{*}{ Profitability } & $-0.259^{* * *}$ & $-0.289^{* * *}$ & $-0.237^{*}$ & $-0.471^{*}$ & $-0.215^{* * *}$ & $-0.449^{* * *}$ & $-0.193^{* * *}$ \\
\hline & $(0.053)$ & $(0.052)$ & $(0.141)$ & $(0.071)$ & $(0.068)$ & $(0.120)$ & $(0.063)$ \\
\hline \multirow{2}{*}{ Investments } & $0.073^{* * *}$ & 0.027 & 0.044 & $0.062^{* *}$ & $0.082^{* * *}$ & 0.026 & $0.051^{* * *}$ \\
\hline & $(0.019)$ & $(0.025)$ & $(0.032)$ & $(0.036)$ & $(0.022)$ & $(0.041)$ & $(0.020)$ \\
\hline \multirow{2}{*}{ Risk } & -0.021 & 0.038 & $-0.928^{* * *}$ & $-0.209^{*}$ & -0.020 & $0.385^{*}$ & $-0.437^{* * *}$ \\
\hline & $(0.075)$ & $(0.075)$ & $(0.255)$ & $(0.091)$ & $(0.104)$ & $(0.224)$ & $(0.089)$ \\
\hline \multirow{2}{*}{ Tax shield } & -0.002 & -0.002 & -0.004 & $-0.010^{* * *}$ & -0.001 & $-0.007^{*}$ & -0.008 \\
\hline & $(0.002)$ & $(0.002)$ & $(0.005)$ & $(0.004)$ & $(0.003)$ & $(0.004)$ & $(0.016)$ \\
\hline \multirow{2}{*}{$\begin{array}{l}\text { Ownership } \\
\text { concentration }\end{array}$} & -0.045 & -0.047 & -0.001 & $-0.002^{* * *}$ & 0.0002 & -0.004 & -0.001 \\
\hline & $(0.032)$ & $(0.031)$ & $(0.001)$ & $(0.001)$ & $(0.001)$ & $(0.004)$ & $(0.001)$ \\
\hline No. of companies & 140 & 125 & 47 & 86 & 86 & 56 & 116 \\
\hline $\begin{array}{l}\text { No. of } \\
\text { observations }\end{array}$ & 834 & 702 & 270 & 502 & 470 & 311 & 646 \\
\hline Adjusted $\mathrm{R}^{2}$ & 0.8353 & 0.8429 & 0.134 & 0.136 & 0.055 & 0.8456 & 0.109 \\
\hline $\mathrm{AIC}$ & -1.8234 & -1.886 & - & - & - & -1.857 & - \\
\hline $\begin{array}{l}\text { Prob } \\
\text { (F-Statistics) }\end{array}$ & 0.000 & 0.000 & 0.000 & 0.000 & 0.000 & 0.000 & 0.000 \\
\hline Model used & $\begin{array}{l}\text { Fixed } \\
\text { effects }\end{array}$ & $\begin{array}{l}\text { Fixed } \\
\text { effects }\end{array}$ & $\begin{array}{c}\text { Random } \\
\text { effects }\end{array}$ & $\begin{array}{c}\text { Random } \\
\text { effects }\end{array}$ & \begin{tabular}{|c|}
$\begin{array}{c}\text { Random } \\
\text { effects }\end{array}$ \\
\end{tabular} & $\begin{array}{l}\text { Fixed } \\
\text { effects }\end{array}$ & \begin{tabular}{|c|}
$\begin{array}{c}\text { Random } \\
\text { effects }\end{array}$ \\
\end{tabular} \\
\hline $\begin{array}{l}\text { Hausman test for } \\
\text { random effects } \\
\text { (prob. Chi-Sq.) }\end{array}$ & 0.0445 & 0.0308 & 0.386 & 0.1161 & 0.3580 & 0.000 & 0.3545 \\
\hline
\end{tabular}

Note: Standard errors in parenthesis. ${ }^{*}$ significant at $10 \%,{ }^{* *}$ significant at $5 \%,{ }^{* * *}$ significant at $1 \%$. Source: Authors' calculations

The robustness tests of the regression results increase our confidence in the above conclusions. Regardless of the grouping of the companies in the sample, leverage is negatively related to the tangibility of assets and the profitability of the company. The impact of company size on leverage is also significant among the manufacturing and the larger companies, while the perceived relationship between the volume of fixed capital investments and the overall leverage is robust to the division of companies by size. The capital structure of the companies seems to follow almost the same characteristics, regardless of their status as being listed or not. The first robustness test is crucial, since it contains only the companies with 
complete data set for the entire period, and it strongly confirms the findings of the general regression model regarding the size, tangibility, profitability and fixed capital investments variables.

\section{Conclusions}

The obtained results of the analysis have shown that the leverage ratios are higher among the larger companies and those investing more heavily in fixed assets, while the profitability and tangibility of assets have a negative impact on leverage. Only the inverse relationship between tangibility and leverage to some extent contradicts our expectations, but it does not seem to be an isolated case when developing countries are concerned. These results are strongly consistent with the pecking order theory, supporting our basic hypothesis that the companies in this region do not set a target capital structure. The indicators that validate this conclusion are as follows: companies that invest in fixed assets borrow more; companies with higher profits borrow less; companies with higher $\mathrm{P} / \mathrm{B}$ ratios do not issue new equity. The tradeoff theory seems to be unsupported most likely due to the relatively low effective tax rates. Most of the results have proven robust to the division of companies by size and by industry, while the most important test on the sample containing only the companies with complete data set has fully confirmed the initial findings. This is the first research to analyze the determinants of capital structure jointly in several of the countries that emerged after the collapse of the former Yugoslav federation. Being based on a sample of companies sharing the same economic background, the research extends the scope of economic insight to the smaller and less frequently explored economies in order to achieve better understanding of their functioning and provide adequate remedies for the problems perceived. However, the study has its own limitations and further research might be useful. First, the number of companies in the sample is limited due to the publicly available data, even though the size of these economies and their capital markets are such that they can be considered sufficiently represented. Second, although with similar backgrounds, the analyzed economies are only a small fraction of the post-transition world. Third, one must have in mind that the time period covered in the analysis (during and after the financial crisis) could have affected the results. Therefore, future research on this topic should be based on larger samples, longer time series of data and possibly unaffected by external shocks, while broadening the research to other posttransition economies might provide more reliable and resolute conclusions. There are several systemic implications of the obtained results. The observed financing patterns of the companies result in constrained corporate growth, stagnation of the stock markets, frozen ownership structures and poorer corporate governance practices. The economies remain bank-centered. The importance of the informal relations between the borrowers and the lenders is detrimental to the development of the small and medium enterprises. The governments should put additional efforts 
to stimulate the primary markets through a development of business angel networks or by stimulating the involvement of the investment funds. It would also be useful to reduce the costs related to new equity and bond issues, since the relatively small amounts of external funding needed rarely justify the costs and efforts of issuing securities. Additionally, the governments could make additional efforts to further reduce the information asymmetries, although a lot has been done in the recent years to increase the transparency of the publicly held companies.

\section{References}

Al-Najjar, B., Taylor, P. (2008) "The relationship between capital structure and ownership structure: New evidence from Jordanian panel data", Managerial Finance, Vol. 34, No. 12, pp. 919-933, doi: 10.1108/03074350810915851.

Akhtar, S., Oliver, B. (2009) "Determinants of Capital Structure for Japanese Multinational and Domestic Corporations", International Review of Finance, Vol. 9, No. 1-2, pp. 1-26, doi: 10.1111/j.1468-2443.2009.01083.x.

Antoniou, A., Guney, Y., Paudyal, K. (2006) "The Determinants of Debt Maturity Structure: Evidence from France, Germany and the UK", European Financial Management, Vol. 12, No. 2, pp. 161-194, doi: 10.1111/j.13547798.2006.00315.x.

Avarmaa M., Hazak A., Männasoo K. (2011) "Capital structure formation in multinational and local companies in the Baltic States", Baltic Journal of Economics, Vol. 11, No. 1, pp. 125-145, doi: 10.1080/1406099x.2011.108404 94.

Baker, M., Wurgler, J. (2002) "Market Timing and Capital Structure”, The Journal of Finance, Vol. 57, No. 1, pp. 1-30.

Bauer, P. (2004) "Determinants of Capital Structure - Empirical Evidence from the Czech Republic", Finance a úvĕr - Czech Journal of Economics and Finance, Vol. 54, No. 1-2, pp. 2-21.

Bena, J., Hanousek, J. (2008) "Rent Extraction by Large Shareholders: Evidence Using Dividend Policy in the Czech Republic", Finance a úvěr - Czech Journal of Economics and Finance, Vol. 58, No. 3-4, pp. 106-130.

Benkato, O. M., Darrat, A. F., Abual-Foul, B. (2005) "Capital Structure of Firms in An Emerging Market: An Empirical Inquiry”, Savings and Development, Vol. 29, No. 1, pp. 97-111.

Berger, P. G., Ofek, E., Yermack, D. L. (1997) "Managerial Entrenchment and Capital Structure Decisions", The Journal of Finance, Vol. 52, No. 4, pp. 14111438, doi: 10.2307/2329441.

Berglöf, E., Pajuste, A. (2005) "What do Firms Disclose and Why? Enforcing Corporate Governance and Transparency in Central and Eastern Europe", 
Sasho Arsov, Aleksandar Naumoski • Determinants of capital structure: An empirical study...

Oxford Review of Economic Policy, Vol. 21, No. 2, pp. 178-197, doi: 10.1093/ oxrep/gri011.

Berk, A. (2007) "The Role of Capital Market in Determining Capital Structure: Evidence from Slovenian Public and Private Corporations", Acta Oeconomica, Vol. 57, No. 2, pp. 123-155, doi: 10.1556/aoecon.57.2007.2.1.

Booth, L. et al. (2001) "Capital Structures in Developing Countries", The Journal of Finance, Vol. 56, No.1, pp. 87-130, doi: 10.1111/0022-1082.00320

Boubaker, S., Lakhal, F., Nekhili, M. (2012) "The determinants of web-based corporate reporting in France", Managerial Auditing Journal, Vol. 27, No. 2, pp. 126-155, doi: 10.1108/02686901211189835.

Chen, J., Chunxia, J., Yujia, L. (2014) "What determine firms' capital structure in China?" Managerial Finance, Vol. 40, No. 10, pp. 1024-1039, doi: 10.1108/ mf-06-2013-0163.

Cvijanović, V., Redžepagić, D. (2011) "From political capitalism to clientelist capitalism - The case of Croatia", Zbornik radova Ekonomskog fakulteta u Rijeci, Vol. 29, No. 2, pp. 355-372.

Črnigoj, M., Mramor, D. (2009) "Determinants of Capital Structure in Emerging European Economies: Evidence from Slovenian Firms", Emerging Markets Finance \& Trade, Vol. 45, No. 1, pp. 72-89, doi: http://dx.doi.org/10.2753/ ree1540-496x450105.

DeAngelo, H., Masulis, R. W. (1980) "Optimal Capital Structure under Corporate and Personal Taxation", Journal of Financial Economics, Vol. 8, No. 1, pp. 3-29, doi: 10.1016/0304-405x(80)90019-7.

Delcoure, N. (2007) "The determinants of capital structure in transitional economies", International Review of Economics \& Finance, Vol. 16, No. 3, pp. 400-415, doi: 10.1016/j.iref.2005.03.005.

Demirgüç-Kunt, A., Maksimovic, V. (1999) "Institutions, Financial Markets, and Firm Debt Maturity", Journal of Financial Economics, Vol. 54, No. 3, pp. 295336, doi: 10.1016/s0304-405x(99)00039-2.

Durnev, A., Kim, E. H. (2005) "To Steal or Not to Steal: Firm Attributes, Legal Environment, and Valuation", The Journal of Finance, Vol. 60, No. 3, pp. 1461-1493, doi: 10.1111/j.1540-6261.2005.00767.x.

Filatotchev, I. et al. (2003) "Governance, organizational capabilities, and restructuring in transition economies", Journal of World Business, Vol. 38, No. 4, pp. 331-347, doi: 10.1016/j.jwb.2003.08.019.

Frank, M. Z., Goyal, V. K. (2004) "The Effect of Market Conditions on Capital Structure Adjustment" Finance Research Letters, Vol. 1, No. 1, pp. 47-55, doi: 10.1016/s1544-6123(03)00005-9.

Friend, I., Lang, L. H. P. (1988) "An Empirical Test of the Impact of Managerial Self-interest on Corporate Capital Structure", The Journal of Finance, Vol. 43, No. 2, pp. 271-281, doi: 10.1111/j.1540-6261.1988.tb03938.x. 
Gonenc, H. (2003) "Capital Structure Decisions under Micro Institutional Settings: The Case of Turkey", Journal of Emerging Market Finance, Vol. 2, No. 1, pp. 57-82, doi: 10.1177/097265270300200103.

Grossman, S. J., Hart, O. (1982) "Corporate Financial Structure and Managerial Incentives", in J. McCall (ed.), The Economics of Information and Uncertainty, University of Chicago, Chicago.

Harris, M., Raviv, A. (1990) "Capital Structure and the Informational Role of Debt", The Journal of Finance, Vol. 45, No. 2, pp. 321-349, doi: 10.1111/ j.1540-6261.1990.tb03693.x.

Harris, M., Raviv, A. (1991) "The Theory of Capital Structure" The Journal of Finance, Vol. 46, No. 1, pp. 297-355, doi: 10.2307/2328697.

Hernádi, P., Ormos, M. (2012) "Capital Structure and Its Choice in Central and Eastern Europe”, Acta Oeconomica, Vol. 62, No. 2, pp. 229-263, doi: 10.1556/ aoecon.62.2012.2.5.

Higgins, R. C. (1977) "How Much Growth Can a Firm Afford?", Financial Management, Vol. 6, No. 3, pp. 7-16, doi: 10.2307/3665251.

Jensen, M. C. (1986) "Agency costs of free-cash-flow, corporate finance, and takeovers", American Economic Review, Vol. 76, pp. 323-329.

Jensen, M. C., Meckling, W. H. (1976) "Theory of the firm: Managerial behavior, agency costs and ownership structure", Journal of Financial Economics, Vol. 3, No. 4, pp. 305-360, doi: 10.1016/0304-405x(76)90026-x.

Jiraporn, P., Gleason., K. C. (2007) "Capital Structure, Shareholder Rights, and Corporate Governance", The Journal of Financial Research, Vol. 30, No. 1, pp. 21-33, doi: 10.1111/j.1475-6803.2007.00200.x.

Jõeveer, K. (2013) "Firm, country and macroeconomic determinants of capital structure: Evidence from transition economies," Journal of Comparative Economics, Vol. 41, No. 1, pp. 294-308, doi: 10.1016/j.jce.2012.05.001.

Kędzior, M. (2012) "Capital structure in EU selected countries - micro and macro determinants", Argumenta Oeconomica, Vol. 28, pp. 69-117.

Keister, L. A. (2004) "Capital Structure in Transition: The Transformation of Financial Strategies in China's Emerging Economy", Organization Science, Vol. 15, No. 2, pp. 145-158, doi: 10.1287/orsc.1040.0043.

Kim, W. S., Sorensen, E. H. (1986) "Evidence on the Impact of the Agency Costs of Debt on Corporate Debt Policy", The Journal of Financial and Quantitative Analysis, Vol. 21, No. 2, pp. 131-144, doi: 10.2307/2330733.

Košak, M., Čok, M. (2008), "Ownership structure and profitability of the banking sector: The evidence from the SEE region", Zbornik radova Ekonomskog fakulteta u Rijeci, Vol. 26, No. 1, pp. 93-122.

MacKie-Mason, J. K., (1990) "Do Taxes Affect Corporate Financing Decisions?" Journal of Finance, Vol. 45, No. 5, pp. 1471-1493, doi: 10.2307/2328746. 
Miller, M.H., (1977) "Debt and taxes", The Journal of Finance, Vol. 32, No. 2, pp. 261-275, doi: 10.1111/j.1540-6261.1977.tb03267.x.

Modigliani, F., Miller, M. (1958) "The Cost of Capital, Corporation Finance, and the Theory of Investment", American Economic Review, Vol. 48, pp. 261-297.

Modigliani, F., Miller, M. (1963) "Corporate Income Taxes and the Cost of Capital: A Correction", American Economic Review, Vol. 53, No. 3, pp. 433-443.

Mramor D., Valentinčič, A. (2001), "When Maximizing Shareholders' Wealth Is Not the Only Choice", Eastern European Economics, Vol. 39, No. 6, pp. 64-93. Myers, S. C. (1977) "Determinants of Corporate Borrowing”, Journal of Financial Economics, Vol. 5, pp. 147-175, doi: 10.1016/0304-405x(77)90015-0.

Myers, S. C. (1984) "The Capital Structure Puzzle", The Journal of Finance, Vol. 39, No. 3, pp. 575-592, doi: 10.2307/2327916.

Myers, S. C., Majluf, N. S. (1984) "Corporate Financing and Investment Decisions when Firms have Information the Investors do not have", Journal of Financial Economics, Vol. 13, No. 2, pp. 187-221, doi: 10.1016/0304-405x(84)90023-0.

Nivorozhkin, E. (2002) "Capital Structures in Emerging Stock Markets: The Case of Hungary", The Developing Economies, Vol. 40, No. 2, pp. 166-187, doi: 10.1111/j.1746-1049.2002.tb01006.x.

Nivorozhkin, E. (2004) "The Dynamics of Capital Structure in Transition Economies", Economics of Planning, Vol. 37, No. 1, pp. 25-45, doi: 10.1007/ s10644-004-1056-2.

Okuda, H., Nhung, L. T. P. (2012) "Capital Structure and Investment Behavior of Listed Companies in Vietnam: An Estimation of the Influence of Government Ownership", International Journal of Business and Information, Vol. 7, No. 2, pp. 137-163.

Peev, E. (2001) "Corporate Governance Transformation in Transition Economies: Evidence from Bulgaria", Vierteljahrshefte zur Wirtschaftsforschung/Quarterly Journal of Economic Research, Vol. 70, No. 2, pp. 289-300, doi: 10.3790/ vjh.70.2.289.

Psillaki, M., Daskalakis, N. (2009) "Are the Determinants of Capital Structure Country or Firm Specific?", Small Business Economics, Vol. 33, No. 3, pp. 319 333, doi: 10.1007/s11187-008-9103-4.

Rajan, R. G., Zingales, L. (1995) "What Do We Know about Capital Structure? Some Evidence from International Data", The Journal of Finance, Vol. 50, No. 5, pp. 1421-1460, doi: 10.1111/j.1540-6261.1995.tb05184.x.

Ribnikar, I., Košak, M. (2011) "Transition, privatization and monetary arrangements in the countries founded on the territory of former Yugoslavia", Zbornik radova Ekonomskog fakulteta u Rijeci - Proceedings of Rijeka Faculty of Economics, Vol. 29, No. 2, pp. 333-353.

Teker D., Tasseven, O., Tukel, A. (2009) "Determinants of Capital Structure for Turkish Firms: A Panel Data Analysis", International Research Journal of Finance and Economics, Vol. 29, pp. 179-187. 
Titman, S., Wessels, R. (1988) "The Determinants of Capital Structure Choice", The Journal of Finance, Vol. 43, No. 1, pp. 1-19, doi: 10.2307/2328319.

Yeoh, P. (2007) "Corporate Governance Models: Is there a Right One for Transition Economies in Central and Eastern Europe?", Managerial Law, Vol. 49, No. 3, pp. 57-75, doi: 10.1108/03090550710816483.

Wen, Y., Rwegasira, K., Bilderbeek, J. (2002) "Corporate Governance and Capital Structure Decisions of the Chinese Listed Firms", Corporate Governance: An International Review, Vol. 10, No. 2, pp. 75-83, doi: 10.1111/1467-8683.00271.

\title{
Determinante strukture kapitala: empirijska studija kompanija iz odabranih post-tranzicijskih ekonomija
}

\author{
Sasho Arsov ${ }^{1}$, Aleksandar Naumoski ${ }^{2}$
}

\begin{abstract}
Sažetak
Cilj ovog rada je ispitati postoje li determinante koje sustavno utječu na strukturu kapitala kompanija na Balkanskom poluotoku i shodno tome, ustvrditi može li se neka od postojećih teorija o strukturi kapitala smatrati primjenjivom u njihovom slučaju. U istraživanju se koristi panel regresija na primjeru najvećih trgovačkih dioničkih društava iz četiriju zemalja. Rezultati regresije pokazuju da veće tvrtke $i$ one s većim investicijama u fiksne fondove imaju veći stupanj zaduženosti, dok profitabilnije tvrtke $i$ one s većim učešćem materijalnih sredstava u ukupnoj aktivi manje koriste financiranje zaduživanjem. Ostale varijable, kao što su koncentracija vlasništva tvrtke, rizičnost njene poslovne dobiti i efektivna porezna stopa se nisu pokazale statistički značajnima. Ovi rezultati, podržani testovima robusnosti, potvrdili su naša očekivanja da menadžeri u ovim zemljama ne postavljaju ciljne kvocijente zaduženosti, već umjesto toga poštuju određeni red u odabiru izvora financiranja. Iz toga proizlazi da se najrelevantnijom od postojećih teorija može smatrati teorija redoslijeda financiranja. Ekonomskim politikama u analiziranim zemljama treba posvetititi veću pozornost u promoviranju ostalih izvora financiranja, kako bi smanjile preveliku ovisnost kompanija o bankarskom sektoru.
\end{abstract}

Ključne riječi: struktura kapitala, tranzicija, stupanj zaduženosti, korporativno financiranje, bankarstvo

JEL klasifikacija: G10, G32, O52

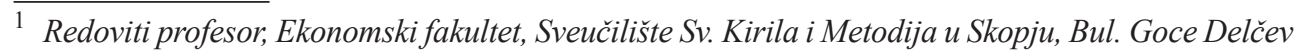
9V, Makedonija. Znanstveni interes: financijski menadžment. Tel.: +389 23286 809, E-mail: sarsov@eccf.ukim.edu.mk. Osobna webstranica: http://www.eccf.ukim.edu.mk/Teacher/52/44 (autor za korespodenciju).

2 Docent, Ekonomski fakultet, Sveučilište Sv. Kirila i Metodija u Skopju, Bul. Goce Delčev 9V, Makedonija. Znanstveni interes: financijski menadžment, upravljanje rizicima. Tel.: +3892 3286 856.E-mail:aleksandar@eccf.ukim.edu.mk. Osobnaweb stranica: http://www.eccf.ukim. edu.mk/Teacher $/ 52 / 68$. 

Sasho Arsov, Aleksandar Naumoski • Determinants of capital structure: An empirical study...

Zb. rad. Ekon.fak. Rij. • 2016 • vol. 34 • no. 1 • 119-146

\section{Appendix}



Sasho Arsov, Aleksandar Naumoski • Determinants of capital structure: An empirical study...

\begin{tabular}{|c|c|c|c|c|c|c|c|c|c|c|c|}
\hline $\begin{array}{l}0 \\
.50 \\
5 \\
0 \\
0\end{array}$ & 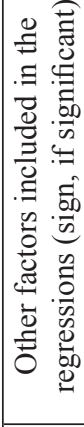 & 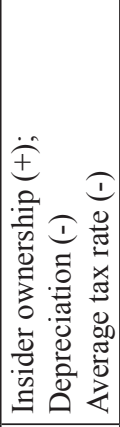 & 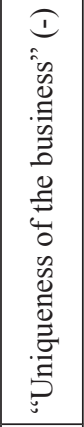 & & 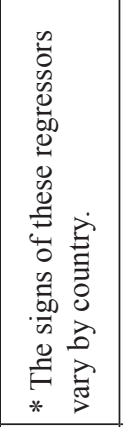 & 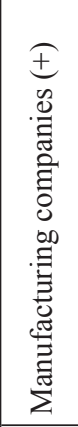 & 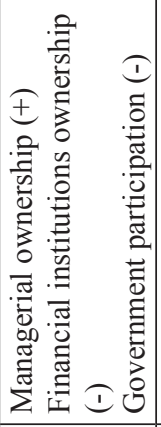 & 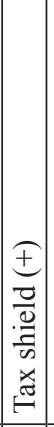 & 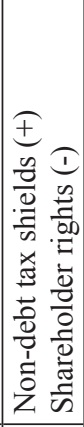 & 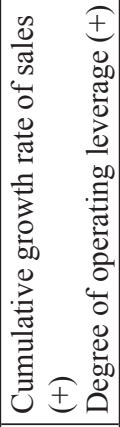 & 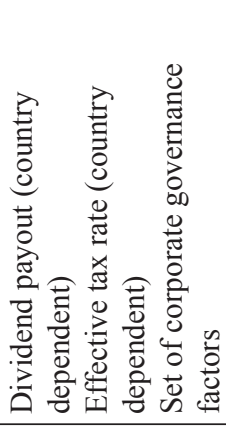 \\
\hline 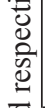 & $\frac{y}{a}$ & + & & & * & & & & & & \\
\hline 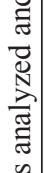 & 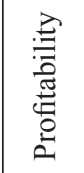 & & I & 1 & ' & $\underbrace{\frac{\pi}{0}}_{1} \frac{\widehat{\theta}}{0}$ & 1 & 1 & ' & ' & ' \\
\hline 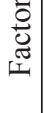 & 营 & ' & & 1 & ' & & 1 & 1 & 1 & & ' \\
\hline & $\stackrel{\mathscr{N}}{\mathscr{n}}$ & & {$\left[\begin{array}{ll}\sqrt{0} & \widehat{0} \\
0 & 0 \\
1 & 0\end{array}\right.$} & + & * & & + & + & + & + & + \\
\hline & 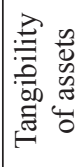 & & & + & 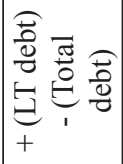 & 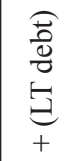 & 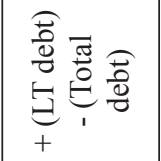 & ' & & + & + \\
\hline & 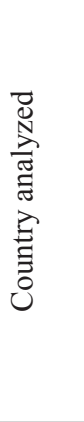 & 芯 & $\begin{array}{l}\mathbb{W} \\
\qquad \\
\square\end{array}$ & 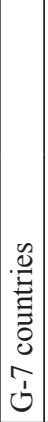 & 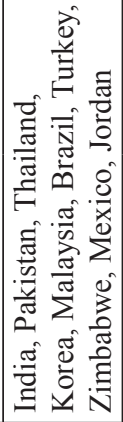 & 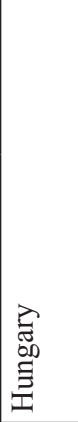 & 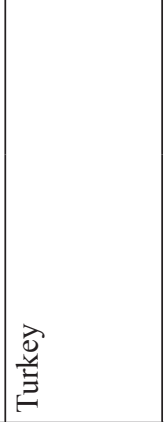 & 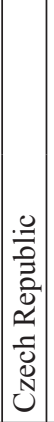 & 虍 & $\mid \begin{array}{l}\cdot \frac{\pi}{10} \\
\frac{0}{2} \\
\frac{0}{\omega}\end{array}$ & 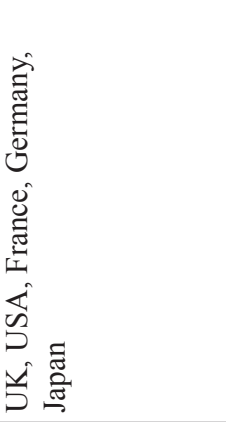 \\
\hline & 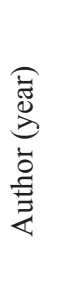 & 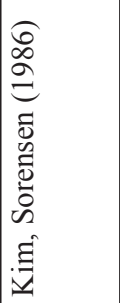 & 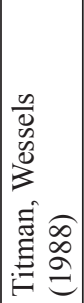 & 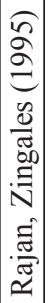 & 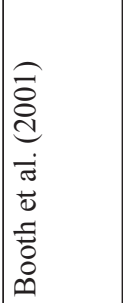 & 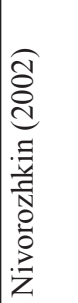 & 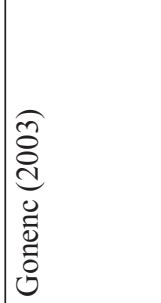 & 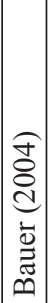 & 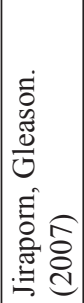 & 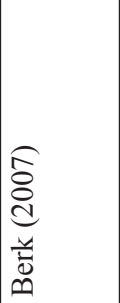 & 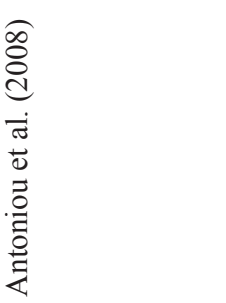 \\
\hline
\end{tabular}


Sasho Arsov, Aleksandar Naumoski • Determinants of capital structure: An empirical study...

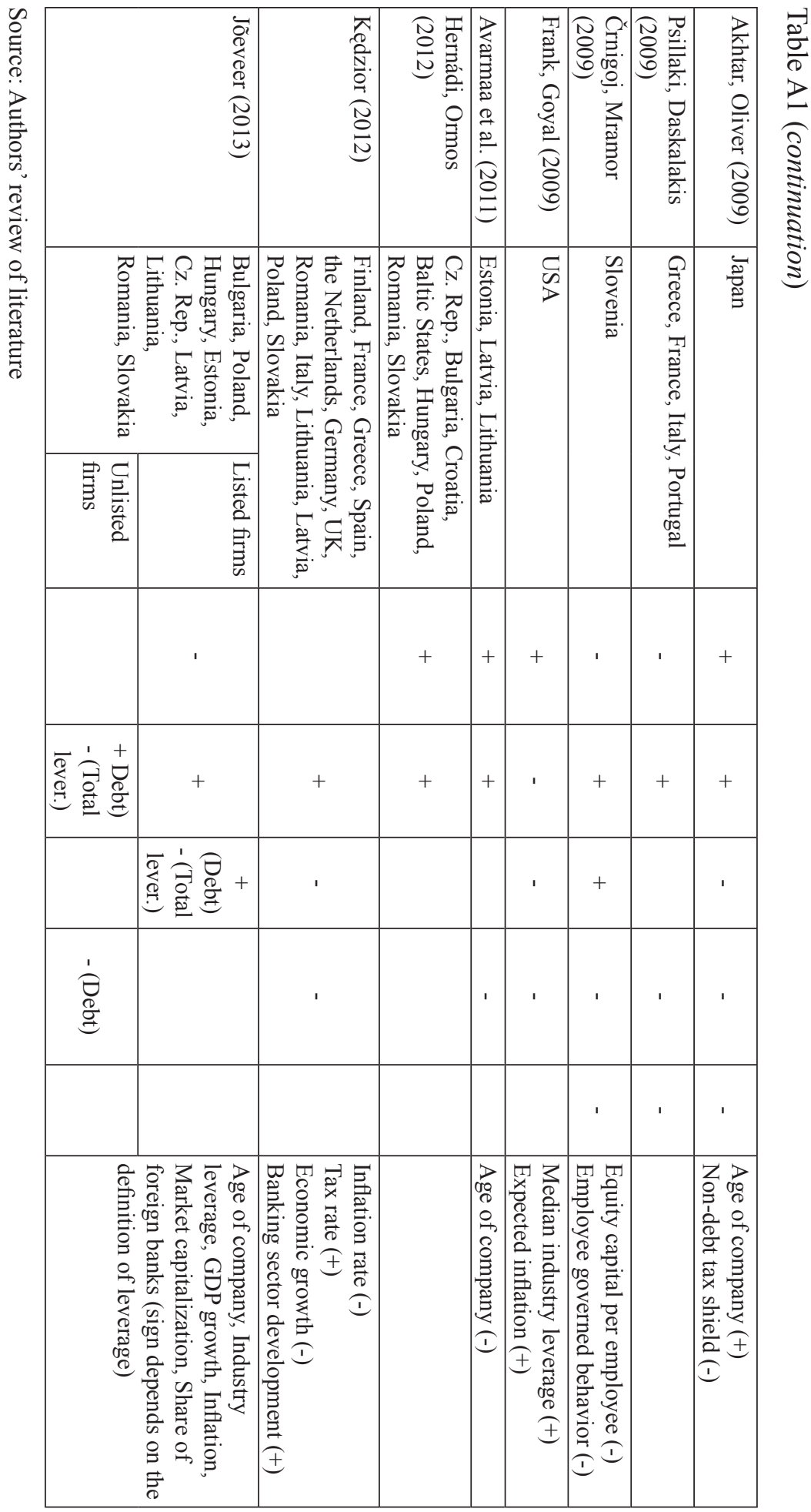

